\title{
Analysis and object-oriented generalization of meteorological data in solving the bioclimatic mapping problem
}

\author{
Vladimir V. Mikhailov ${ }^{1}$ \\ ${ }^{1}$ St. Petersburg Federal Research Center of the Russian Academy of Sciences, Saint-Petersburg, Russia
}

\begin{abstract}
The focus of the paper is interrelation and character of changes in climate factors in Taimyr and the North of Evenki in the summer-autumn period between 1970 and 2020. Bioclimatic fields of the reindeer range as a form of object-oriented generalization of meteorological data have been constructed for the "average" and the most contrasting years in terms of temperature indices.
\end{abstract}

\section{Keywords}

Bioclimatic mapping, meteorological factors, correlation, cluster relationship structure, data reconstruction, model, bioclimatic fields.

\section{Introduction}

The concept of "bioclimate" in modern bioclimatology is interpreted very broadly. Bioclimate is treated as the climate of biota; as climatic conditions that determine, among other environmental factors, the existence, development and reproduction of living organisms; as the effect of climate on the human body or other living beings. Climatic factors produce direct and indirect effect on living beings. Direct impacts can cause overheating, hypothermia, dehydration of the body or, for example, transport by wind, etc. Indirect impacts of climate are due to changes in foraging, mosquito population densities, the development of infectious diseases and changes in other indicators. Direct and indirect impacts of climate factors can also be identified for plant communities or mosquito populations. We believe that bioclimatic issues are concerned specifically with direct effects of weather and climate factors on animals or other components of ecosystems. Indirect impacts go beyond those that are purely climatic. These are predator-prey, parasite-host or other interactions. The indirect effects of climate factors can be taken into account within these interactions.

Under this approach, the main objectives of bioclimatic research are as follows.

1. The determination of the composition of meteorological factors directly affecting the animal's organism and the formation of an array of meteorological data for the area under study.

2. The determination of the criterion index that characterizes the state of the animal's organism or its comfort level depending on the values of meteorological factors.

SDM-2021: All-Russian conference, August 24-27, 2021, Novosibirsk, Russia

Đmwwcari@gmail.com (V.V. Mikhailov)

(c) (1) $\odot 2021$ Copyright for this paper by its authors. Use permitted under Creative Commons License Attribution 4.0 International (CC BY 4.0).

CEUR Workshop Proceedings (CEUR-WS.org) 
3. The identification of the connection between the values of climatic factors and the value of the criteria index, i.e. the construction of the bioclimatic model of the ecosystem component.

4. The calculation of the values of the criterion index in different spots of the territory on the model and the construction of a bioclimatic field by approximation.

The strength of the field at one or another point corresponds to the criterion indicator values and thus characterizes the degree of favorability of the area for living organisms depending on the existing or projected values of meteorological factors. In this work, the animal thermal balance model $[1,2]$ is used to construct the bioclimatic fields of the reindeer habitat

The study area is the Taimyr Peninsula and Northern Evenki, and the subject of bioclimatic research is reindeer $[3,4,5]$.

In order to reasonably approach the determination of the bioclimatic structure of the animal range, it is necessary to assess the characteristics of the territory's climate. Under warming conditions, it is necessary to identify trends in climatic factors, assess inter-annual changes in factors, and identify the most contrasting and average years for bioclimatic calculations. Accordingly, the work consists of two parts. The first one investigates the dynamics of climatic factors in the seasons with positive air temperature in the interval from 1970 to 2020, assesses the correlations, reconstructs the missing data, and selects the most significant years for bioclimatic calculations. These studies significantly complement the results of the climatic analysis of the territories of Northern Middle and Western Siberia [2], belonging mainly to the southern part of the reindeer range (forest-tundra and northern taiga zone).

In the second part, model calculations are performed and bioclimatic fields of the habitat are constructed for July, the warmest month in the North of Middle Siberia.

\section{Analysis and reconstruction of meteorological data}

We used the data of hydro-meteorological stations (HMS) on the territory of Taimyr and the North of Evenki (Table 1) in the interval from 1970 to 2020 in the seasons with positive air temperatures (June-October). The choice of seasons with positive air temperatures is determined by the following reasons. Reindeer are well adapted to harsh winter conditions. The lowest critical air temperature for adult males is $-62{ }^{\circ} \mathrm{C}$ and for females $-58{ }^{\circ} \mathrm{C}$. These temperatures are much lower than those actually observed in reindeer wintering grounds [2]. In summer, at air temperatures above $20^{\circ} \mathrm{C}$ (with open sun above $15^{\circ} \mathrm{C}$ ), the physiological thermoregulatory system cannot provide reindeer with a thermal balance. Overheating is eliminated by reducing the metabolic rate. However, with low activity, animals do not have time to gain normal biomass in summer, which affects their reproductive ability and mortality rate in the winter period $[3,10]$. The following meteorological factors were used: air temperature, wind speed, precipitation, total cloudiness, air humidity, direct and diffused solar radiation. Data averaging is monthly average. The data on air temperature, the main factor determining the degree of well-being and the possibility of survival of the components of polar ecosystems, were investigated most carefully.

The plots of changes in monthly average air temperatures between 1970 and 2020, as well as the plots of the sums of positive temperatures were built for the permanently operating stations. 


\section{Table 1}

The data about HMS.

\begin{tabular}{lcccc}
\hline BMO & Meteorological station & Latitude, ${ }^{\circ}$ n.l. & Longitude, ${ }^{\circ}$ e.l. & Altitude, $\mathrm{m}$ \\
\hline 20087 & Golomyannyi Island & 79.50 & 90.617 & 8 \\
20274 & Uedineniya Island & 77.500 & 82.200 & 23 \\
20289 & Russkyi Island & 77.183 & 96.583 & 9 \\
20292 & Cheluskin Cape & 77.717 & 104.300 & 15 \\
20476 & Sterligov Gulf & 75.417 & 88.900 & 11 \\
20594 & Taimyr Lake & 74.500 & 102.500 & 11 \\
20674 & Dikson Island & 73.500 & 80.400 & 47 \\
20679 & Ust-Tareya & 73.250 & 90.917 & 21 \\
20696 & Kosystyi Cape & 73.650 & 109.750 & 20 \\
20891 & Khatanga & 71.983 & 102.467 & 33 \\
20982 & Volochanka & 70.967 & 94.500 & 40 \\
21405 & Pronchistcheva Gulf & 75.533 & 113.517 & 15 \\
21802 & Saskylah & 71.967 & 114.083 & 18 \\
21908 & Galinda & 70.133 & 113.967 & 62 \\
23074 & Dudinka & 69.400 & 86.167 & 19 \\
23274 & Igarka & 67.467 & 86.567 & 31 \\
23383 & Agata & 66.883 & 93.467 & 278 \\
23472 & Turukhansk & 65.783 & 87.933 & 38 \\
24105 & Essey & 68.467 & 102.367 & 271 \\
24125 & Olenek & 68.500 & 112.433 & 220 \\
24507 & Tura & 64.266 & 100.233 & 168 \\
\hline
\end{tabular}

Table 2

Temperature growth by linear trend and range of deviations.

\begin{tabular}{|c|c|c|c|c|c|c|c|}
\hline $\begin{array}{l}\text { Hydro- } \\
\text { meteorological } \\
\text { stations }\end{array}$ & $\begin{array}{l}\text { June, } \\
{ }^{\circ} \mathrm{C}\end{array}$ & ${ }^{\circ} \mathrm{July}$ & $\begin{array}{l}\text { August, } \\
{ }^{\circ} \mathrm{C}\end{array}$ & $\begin{array}{c}\text { September, } \\
{ }^{\circ} \mathrm{C}\end{array}$ & $\begin{array}{l}\text { Variation } \\
\text { range, } \\
\quad{ }^{\circ} \mathrm{C}\end{array}$ & $\begin{array}{c}\text { Sum of positive } \\
\text { temperatures, } \\
{ }^{\circ} \mathrm{C}\end{array}$ & $\begin{array}{c}\text { Sum } \\
\text { increase, } \\
\%\end{array}$ \\
\hline Cheluskin Cape & & 0.23 & 2.15 & & 2.5 & $40+70$ & 175 \\
\hline Sterligov Gulf & & 2.05 & 3.25 & 2.7 & 3.5 & $140+160$ & 114 \\
\hline Dikson Island & 3.85 & 2.95 & 2.8 & & 3 & $230+280$ & 78 \\
\hline Dudinka & & 1.9 & & & 4 & & \\
\hline Igarka & 4.3 & 1.1 & 0.45 & 2.4 & 4 & $1140+240$ & 21 \\
\hline Agata & 2.2 & 0.16 & 0.95 & 1 & 2.5 & $1940+265$ & 15 \\
\hline Turukhansk & 3.7 & 1.2 & 0.52 & 1.4 & 3 & $1280+310$ & 24 \\
\hline Tura & 3.9 & 1.1 & 0.85 & 0.85 & 3.5 & $1420+285$ & 20 \\
\hline Taimyr Lake & & 0.6 & & & 4 & & \\
\hline Ust-Tareya & & 1.85 & & & 4 & & \\
\hline Kresty & & 1.45 & & & 3 & & \\
\hline Volochanka & & 1.3 & & & 4 & & \\
\hline Khatanga & 6 & 0.5 & 0.9 & 2.15 & 4 & $770+285$ & 36 \\
\hline Essey & & 0.38 & & & 5 & & \\
\hline Olenek & 4.7 & 0.18 & 0.8 & 1 & 4.5 & $1060+270$ & 25 \\
\hline Galinda & 4.3 & 0.85 & 1.7 & 2 & 3.5 & $950+265$ & 27 \\
\hline
\end{tabular}


The linear and quadratic trends of the variables were determined from the plots. The resulting data on the temperature rise over the interval by the linear trend and the range of inter-annual deviations from the trend are presented in Table 2.

As can be seen from the table, the largest increase in monthly average air temperature for 50 years at the inland stations occurred in June (about $4{ }^{\circ} \mathrm{C}$ ), in July and August the temperature fell to 1.2 and $0.8^{\circ} \mathrm{C}$, respectively. In September, it increased slightly to $1.4^{\circ} \mathrm{C}$. At the coastal stations of the Kara Sea, the temperature increase in July-August averaged $2.7^{\circ} \mathrm{C}$. At Cape Cheluskin the temperature did not change significantly in July (increase of $0.23^{\circ} \mathrm{C}$ ), while in August it rose by $2.15^{\circ} \mathrm{C}$.

The range of deviations of the monthly temperature from the trend is $\pm 4{ }^{\circ} \mathrm{C}$ on average for the stations.

The sum of positive temperatures at Cape Cheluskin due to temperature increase in August rose almost 3-fold due to the initial low sum. For Sterligov Gulf, the sum temperatures increased by about a factor of 2 for the same reason. For all the other stations (including Dixon) the increase in the sum is about the same and amounts to $275 \pm 35{ }^{\circ} \mathrm{C}$ (about $24 \%$ of the initial sum).

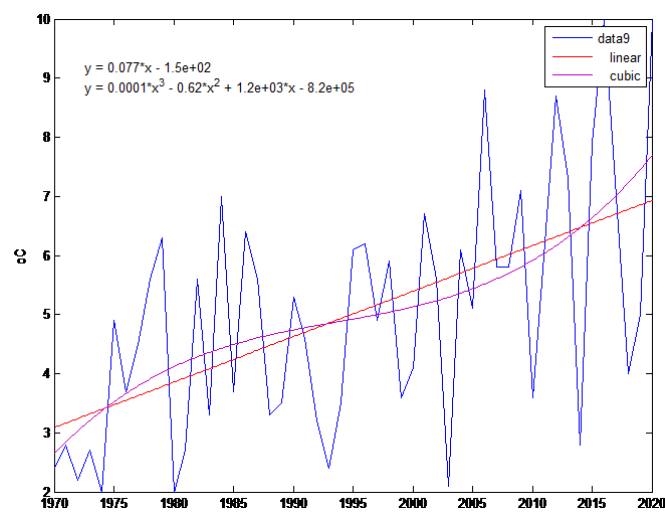

C

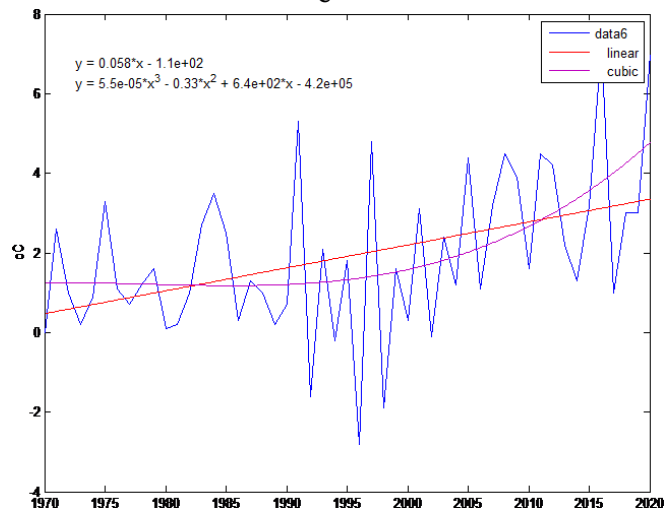

$\mathrm{b}$

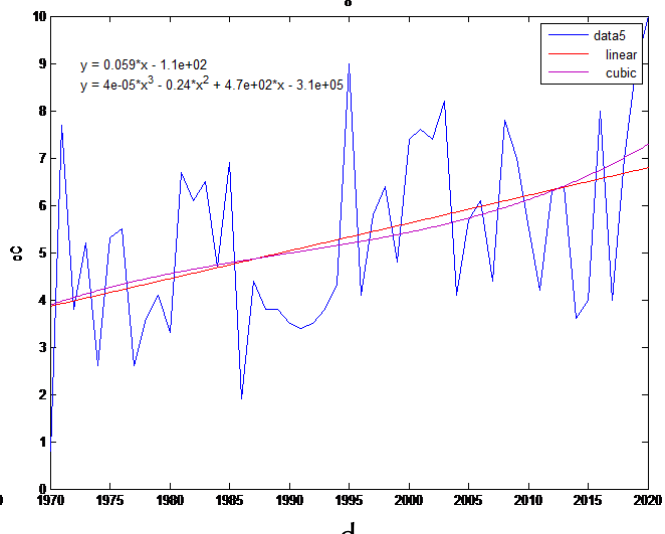

st

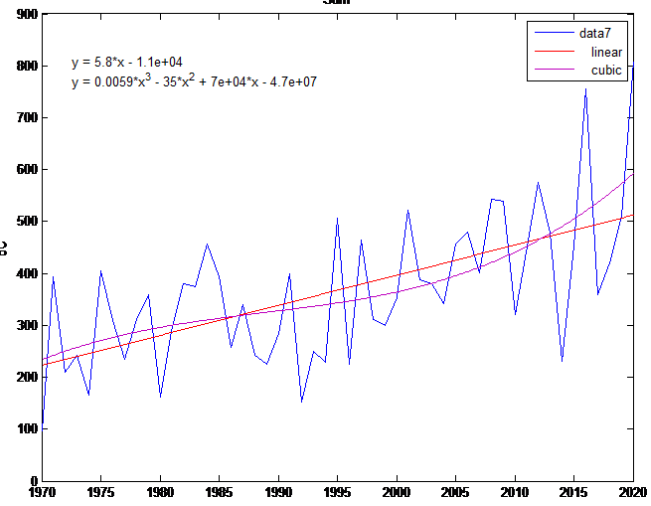

Figure 1: Dikson, inter-annual dynamics of monthly average air temperature. $a-$ June, $b-$ July, $c-$ August, $d-$ sum of positive temperatures. 

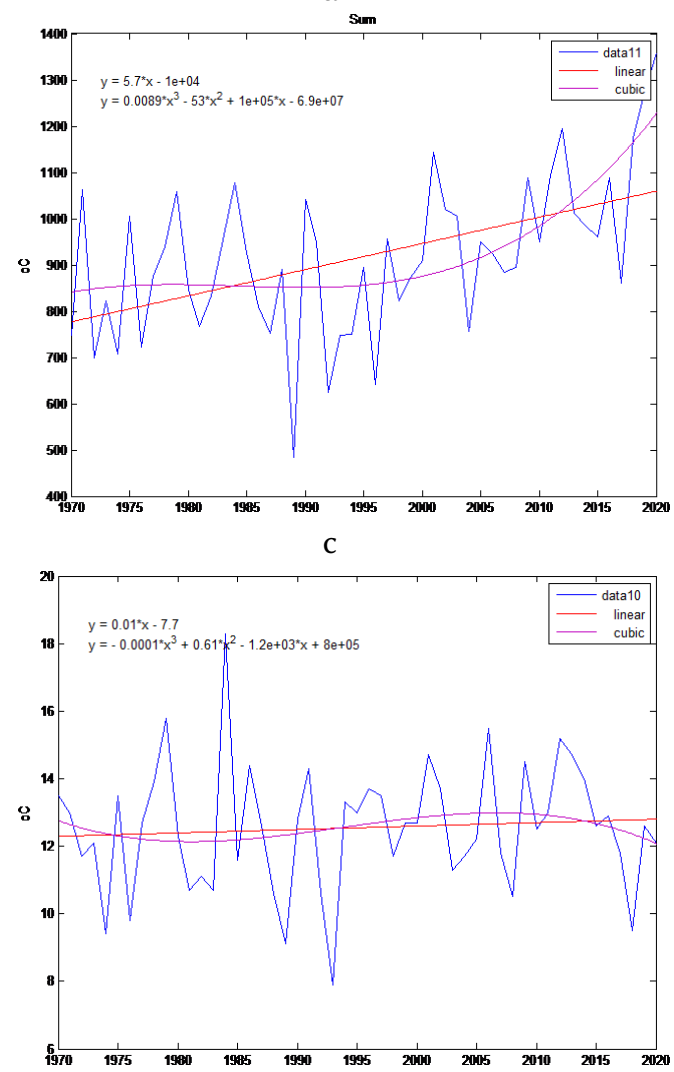

$\mathrm{b}$

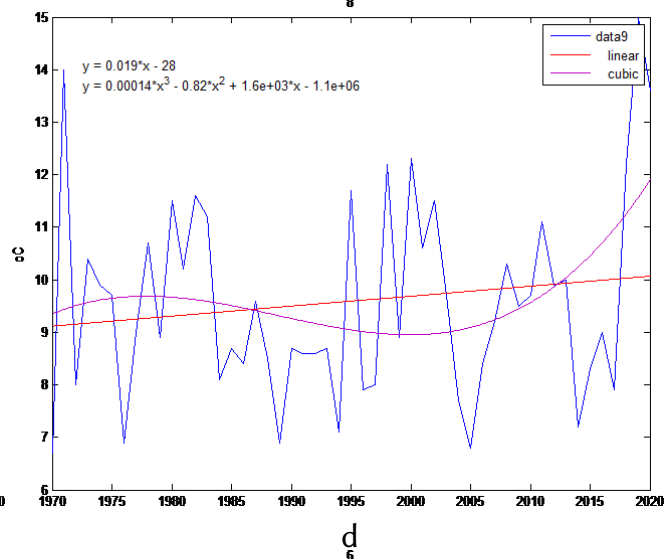

$d_{6}^{d}$

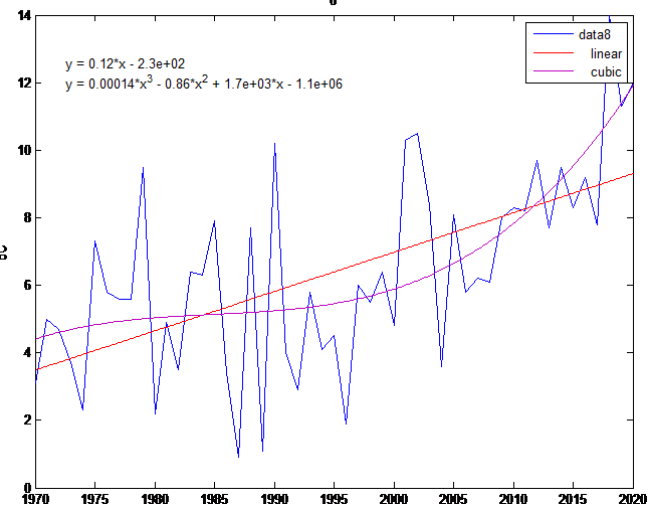

$e_{9}$

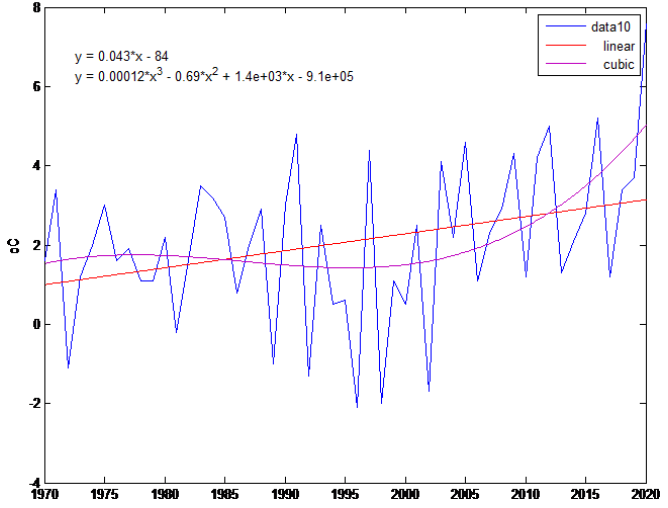

Figure 2: Khatanga, interannual dynamics of monthly average air temperature. $a-J u n e, b-J u l y, c-$ August, $\mathrm{d}-$ September, $\mathrm{e}-$ sum of positive temperatures.

As an example in Figures 1-2 the plots of average monthly air temperatures for weather stations Dikson and Khatanga are shown. The largest temperature increase at the stations along a linear trend occurred in June. At Dikson the temperature increased by $4{ }^{\circ} \mathrm{C}$, at Khatanga by almost $6{ }^{\circ} \mathrm{C}$. But the average July temperature in Khatanga increased by only $0.5^{\circ} \mathrm{C}$ during the period of 50 years and by almost $3{ }^{\circ} \mathrm{C}$ at Dikson. 
As can be seen from the graphs, the temperature increase along a quadratic trend has accelerated since 2005, after its relative stabilization in 1980-2000. The studies have shown that this trend is characteristic of temperature variations for most of the stations presented in Table 1.

The next stage of meteorological data processing consisted in determining the correlation relations between the series of average July air temperature for all permanently operating stations (Table 1). The correlation coefficients were calculated for the time period between 1970 and 2016 and for its individual intervals. The first coefficient conditionally corresponds to the low level of warming (1970-1987), the second one (1988-2002) - to the average level, and the third one (2003-2016) - to the high level. The connections with correlation coefficients of less than 0.6 were not considered. Based on the results of the calculations, the weather stations were grouped into clusters. A cluster contains the stations with a complete set of relations (each station is related to each other).

The clustering results are presented in Table 3. As can be seen from the table, climate change leads to a decrease in the temperature stability of the system. The size of clusters decreases. Two-component clusters and isolated weather stations appear. However, the value of the correlation coefficient values and the corresponding cluster relationship structure determined from the long data series (1970-2016) is almost unchanged compared to the results obtained from the 1979-1987 data.

In the 1990s, the meteorological stations Ust-Tareya, Taimyr Lake, Kresty on the Pyasin, and Essey ceased operation. Since the data from these stations are extremely significant for constructing bioclimatic fields, we made an attempt to reconstruct the series of monthly

Table 3

HMC clustering by correlation relationships.

\begin{tabular}{|c|c|}
\hline $\begin{array}{c}\text { Counting } \\
\text { interval }\end{array}$ & Clusters \\
\hline \multicolumn{2}{|r|}{ Northern group of stations } \\
\hline $\begin{array}{l}1970-1987 \\
1988-2003 \\
2004-2016 \\
1970-2016\end{array}$ & $\begin{array}{c}\text { (Sterligov - Dikson - Dudinka - Khatanga), (Cheluskin - Khatanga) } \\
\text { (Sterligov - Dikson - Khatanga), (Cheluskin), (Dudinka) } \\
\text { (Sterligov - Khatanga), (Sterligov - Dikson), (Dikson - Dudinka), (Cheluskin) } \\
\text { (Sterligov - Dikson - Dudinka - Khatanga), (Cheluskin) }\end{array}$ \\
\hline \multicolumn{2}{|r|}{ Southern group of stations } \\
\hline $\begin{array}{l}1970-1987 \\
1988-2003 \\
2004-2016 \\
1970-2016\end{array}$ & $\begin{array}{c}\text { (Igarka - Agata - Turukhansk - Tura), (Tura - Olenek - Galinda), (Igarka - Galinda) } \\
\text { (Igarka - Agata - Turukhansk - Tura), (Tura - Olenek - Galinda) } \\
\text { (Igarka - Agata - Turukhansk), (Tura - Olenek - Galinda), (Igarka - Tura) } \\
\text { (Igarka - Agata - Turukhansk), (Tupa - Olenek - Galinda), (Igarka - Tura), } \\
\text { (Turukhansk - Tura) }\end{array}$ \\
\hline \multicolumn{2}{|r|}{ Intergroup relations } \\
\hline 1970-2016 & $\begin{array}{c}\text { (Dikson - Khatanga - Dudinka - Agata), (Khatanga - Olenek - Galinda), } \\
\text { (Dudinka - Igarka - Turukhansk) }\end{array}$ \\
\hline
\end{tabular}


July temperatures using regression models. The model arguments were selected taking into account the values of correlation coefficients between the temperature series of simulated and continuously operating stations. The coefficients were calculated using the data from 1970-1987, when the entire network of weather stations was in operation. If the correlation coefficient exceeded 0.6, the station was included in the list of argument stations, otherwise - it was discarded. The data series from 1970-1987 from argument stations were used for model runs, and the data series from 1988-2020 were used for forecasting. Below, a list of arguments is presented for each of the models, with the corresponding values of correlation coefficients in brackets:

Essey: Khatanga (0.81), Olenek (0.6), Tura (0.62), Jalinda (0.71).

Tareya: Sterligov (0.8), Dikson (0.74), Khatanga (0.78), Dudinka (0.82), Agata (0.66), Igarka (0.72).

Kresty: Sterligov (0.8), Dikson (0.72), Khatanga (0.82), Dudinka (0.92), Agata (0.84), Igarka (0.91), Turukhansk (0.69), Tura (0.73).

Lake Taimyr. Taimyr: Cheluskin (0.62), Sterligov (0.7), Dikson (0.61), Khatanga (0.87), Dudinka (0.67), Igarka (0.62).

As it was shown earlier, the correlation coefficients for permanently operating stations calculated by the 1970-1987 and 1970-2016 data turned out to be sufficiently close. Thus, it can
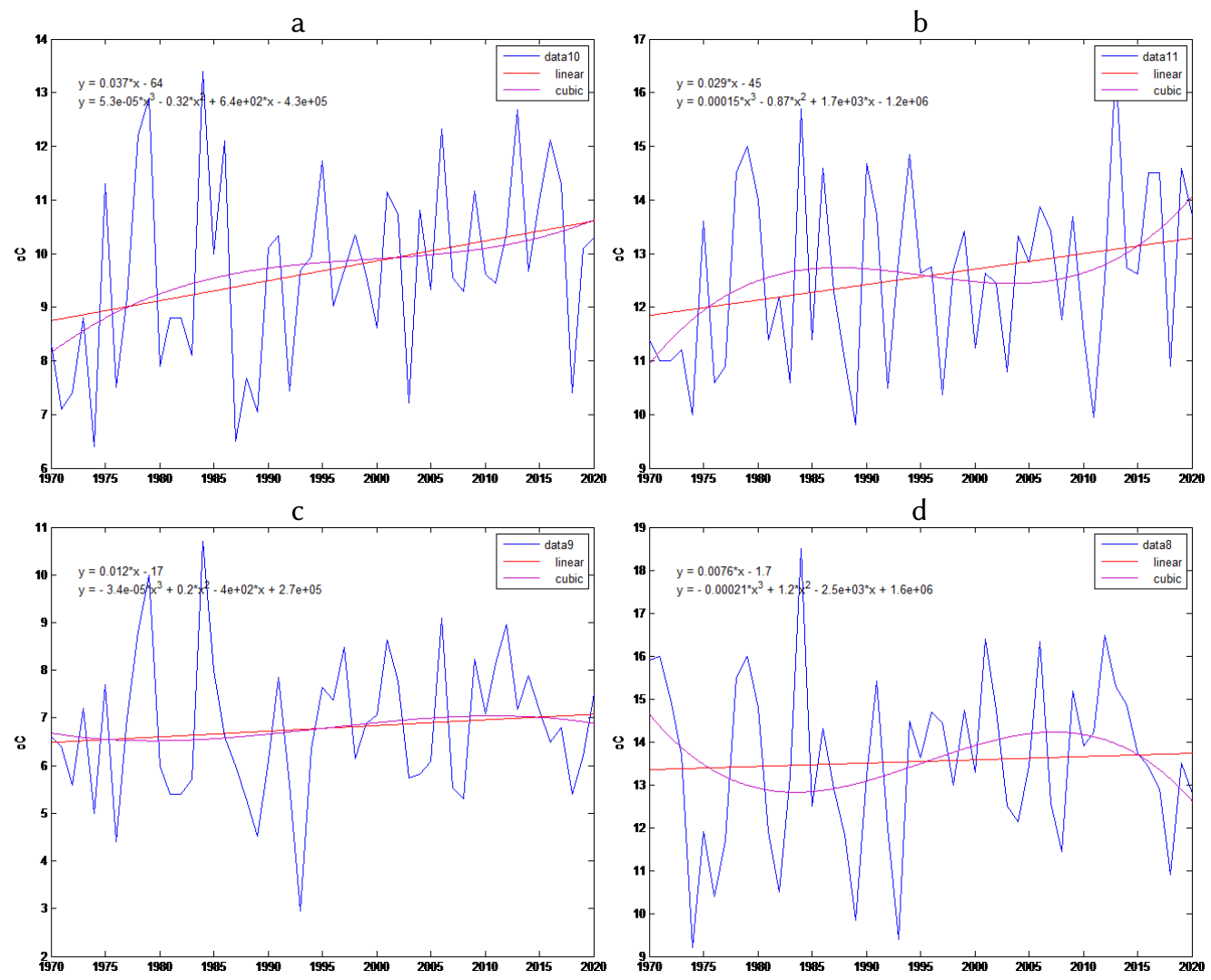

Figure 3: Average July air temperature, linear and quadratic trends for Ust-Tareya (a), Kresty on Pyasin (b), Taimyr Lake (c) and Essey (d) HMS. 
be assumed that the cluster structure of correlation relations between permanently operating and closed stations in general has not changed significantly either and regression dependences, constructed using short data series, can be applied for forecast calculations. An additional check was made for the Volochanka HMS. A regression model was built for this station and the predicted and actual temperature values for the interval from 2008 to 2020 were compared. The root-mean-square deviation of the calculated data from the actual data was $9.2 \%$. The average temperature value over the interval according to the calculated data is $13.6^{\circ} \mathrm{C}$ and according to the actual data $13.5^{\circ} \mathrm{C}$.

Figure 3 shows the reconstructed data about the course of avarage July temperature from 1970 to 2020 for the continental stations in Taimyr and the linear and quadratic trends in temperature.

Based on the analysis of average July temperatures for all the stations considered, the years with maximum and minimum air temperatures were selected for bioclimatic calculations. The warmest year was 1984 (average July temperature for all HMS was $14.5^{\circ} \mathrm{C}$ ), the coldest -1974 (average temperature $8.8^{\circ} \mathrm{C}$ ). In the $21^{\text {st }}$ century, the warmest year was 2012 and the coldest was $2018\left(14\right.$ and $\left.9.6^{\circ} \mathrm{C}\right)$. The first pair of years was chosen for the calculations, because at this time all the weather stations were operating and it was possible to use the actual data rather than the predicted values. 1970 and 2014 were the "average" years and the closest years to a linear temperature trend at the boundaries of the 1970-2020 interval. The average temperature was 11.1 and $11.8^{\circ} \mathrm{C}$.

\section{The bioclimatic structure of the reindeer range in Taimyr}

When determining the bioclimatic structure of the range, we relied on the concept of thermoneutrality, interpreted in a broad sense as the ability of the animal organism to maintain a thermal balance in a certain range of values of weather and climate factors through the work of the physiological system of thermoregulation without changes in heat production, aimed exclusively at eliminating overheating or overcooling of the body. In physiology this range of factor values is referred to as the heat comfort zone of animals (HCZ). This idea corresponds to biological concepts of thermoregulation in warm-blooded animals $[6,7,8,9]$. In contrast to $\mathrm{HCZ}$, the thermoneutral zone concept (TNZ) characterizes only the temperature factor effect. Thus, according to [8], TNZ is the temperature range in which the intensity of metabolism does not depend on temperature; according to (GOST R ISO 14505-3-2010) TNZ is the range of ambient temperatures at which the body maintains its thermal balance solely through vasomotor reactions.

In real natural conditions animals are always under the complex influence of climatic and radiation factors. In this regard, the heat comfort zone characterizes the bioclimatic structure of the habitat more reliably than TNZ. However, it is very difficult to define the boundaries of the zone and metricize its bioclimatic structure, taking into account the complex nature of the impact of meteorological factors and the joint work of different physiological systems of reindeer thermoregulation. This has prompted the use of modelling methods. A special version of the heat balance model has been developed to assess the level of animal comfort. A detailed description of the biological rationale, the mathematical structure and the results of validation experiments is available in $[1,2]$. For this reason, we will limit ourselves to a brief description of 
the model's features.

The model belongs to the class of compartmental models and has two layers. The first layer is represented by the "core" compartment and the second one - by the "shell" compartments (shells of head, neck, torso, upper and lower parts of forelimbs, upper and lower parts of hind limbs). This structuring is related to the peculiarities of the thermal characteristics of the animal body and the availability of the information required to set up the model $[10,11]$.

The model implements an active heat flow regulation system. Within HCZ, regulation is accomplished by changing the thermal conductivity of the coat and sheath tissues, as well as the heat output of the respiratory system. The difference of heat production and heat dissipation is used as a regulated value, balancing both within a separate phase of animal behavior (movement, resting, feeding) and the cycle of these phases in the daily time budget [12]. Beyond the HCZ boundary, the thermal balance is established by changing the heat production value. Overcooling is compensated by activation of chemical regulatory mechanisms (cold muscle tremors and cold muscle tone) that increase the body's heat production. The maintenance of the thermal balance during overheating is ensured by reducing the level of metabolism and, consequently, the heat production of the animal's organism $[6,10]$.

The intensity of the impact of climatic factors on the animal's body outside the $\mathrm{HCZ}$ can be estimated by the relative energy imbalance $T I$ :

$$
T I=(P L-P P) / P P,
$$

where $P P$ is normal heat production, $P L$ is heat loss.

With overheating $P P>P L, T I<0$, with sub cooling $P P<P L, T I>0$.

In the zone of thermal comfort there is a balance $P P \approx P L$, maintained due to the work of the thermoregulation system. From the energy point of view, the zone is homogeneous in terms of intensity, and there is no energy imbalance. However, the zone is not homogeneous in terms of the intensity of the thermoregulation system of the animal.

The methodology we use to determine the bioclimatic structure is based on the assumption: the intensity of exposure to climatic factors within the HCZ can be estimated from the state of the thermoregulation system. The weighted additive convolution was used as an indicator of the thermoregulation system condition, the weights in which were chosen to be proportional to the contribution of the subsystems to the total value of heat output of the animal's organism. A measure of the severity of the impact of climatic factors on animals is the normalized value of the convolution. Rationing is performed in such a way that at the upper boundary of HCZ intensity index $K=1$, at the lower boundary $K=0$. Outside the $\mathrm{HCZ}$, the relative value of imbalance of heat production and body heat loss is added to the tension value at the boundary. In case of overheating the value of tension index $\mathrm{K}<0$, in case of undercooling $K>1$. The higher the stress index is relative to unity or the lower the stress index is relative to zero, the higher energy cost must be paid by the animal to restore its heat balance. Energy imbalance leads to a decrease in protective and reproductive performance of animals, as a result of which reindeer cannot survive in such conditions for a long time.

The procedure for creating areal bioclimatic fields includes preparing the necessary meteorological information, conducting calculations on the heat balance model to determine the intensity of the impact of climatic factors in given locations, and constructing the isolines of the intensity fields using GIS technologies. 


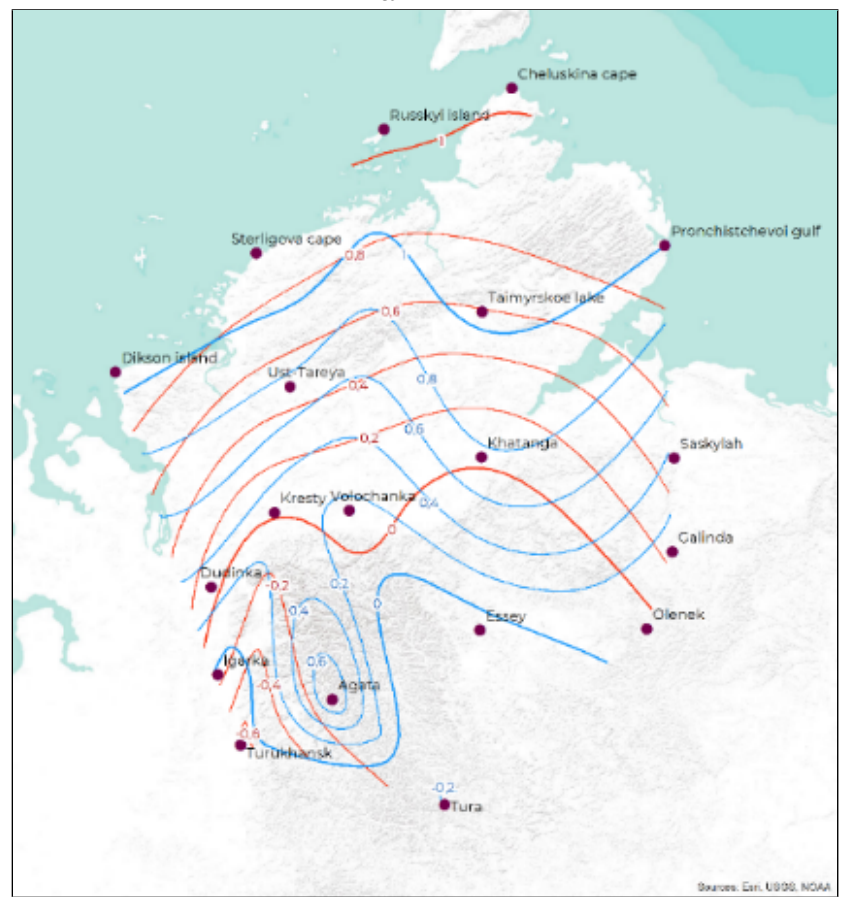

b

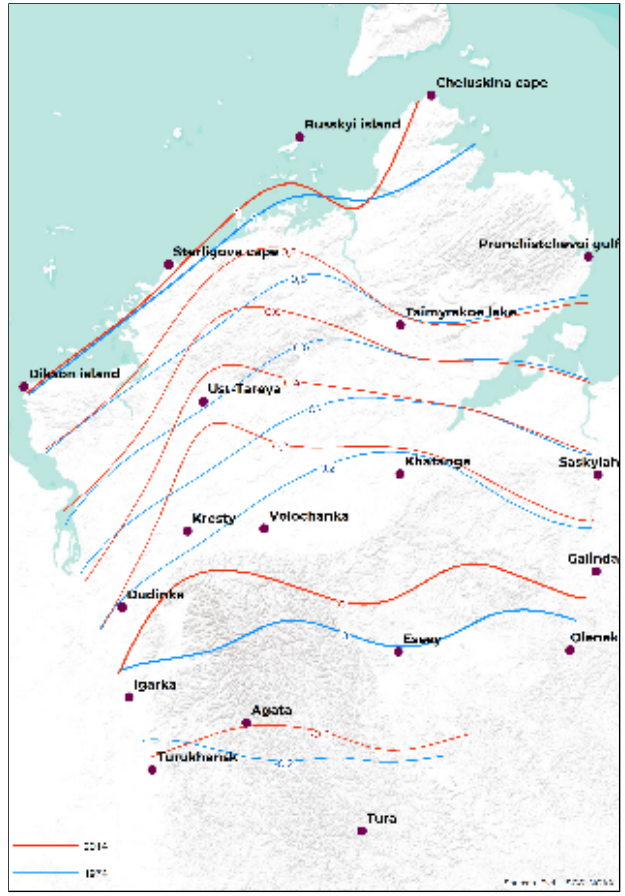

Figure 4: Reindeer bioclimatic fields for average July temperature. a - 1974 the coldest, $1989-$ the warmest. b - middle years - 1973 and 2014.

Figure 4 shows reindeer bioclimatic fields for two years with contrasting average July temperatures: 1974 - the coldest and 1989 - the warmest, and the middle years - 1973 and 2014, as it was markets early. As can be seen from the figures, the maximum inter-annual shifts of the Taimyr HCZ boundaries in July are about $150 \mathrm{~km}$ or more. Shifts associated with climate warming are considerably smaller, amounting to only about $40 \mathrm{~km}$ over 40 years.

\section{Conclusion}

The bioclimatic approach was used to analyze the spatial structure of the Taimyr wild reindeer population. It was found that the seasonal movements of reindeer in Taimyr and northern Evenki allow the animals to remain in favorable conditions, maintaining a stable heat balance. At the same time, during the most important periods for the well-being of the population calving and autumn fattening - the animals are located in areas with optimal bioclimatic conditions $(0.4<K<0.6)$ [2].

In domestic reindeer husbandry, herds traditionally graze in the areas with the most favorable bioclimatic conditions, and reindeer herders adhere to these even when forage resources are significantly depleted. In the past decades, a significant growth of the reindeer population was only observed in the tundra regions of Western Siberia, a region with scarce pastures, but also with better climatic conditions for reindeer husbandry [13]. Modelling was used to identify the areas of climatic optimum for traditional reindeer husbandry of indigenous peoples of Siberia 
and the Far East [14].

The bioclimatic approach can be applied to other species, birds or other ecosystem components to identify seasonal range dynamics in relation to climatic conditions. By overlapping fields, problem areas can be identified, e.g. areas of the reindeer HCZ that are also climatically favorable for the breeding of blood-sucking insects or gadflies.

SCILAB and QGIS software packages were used for calculations and mapping.

\section{Acknowledgments}

The work was carried out in the framework of the budgetary theme 0073-2019-0004.

\section{References}

[1] Mikhailov V.V. Model of regulation of the heat balance of the reindeer as part of the software integrated monitoring system // SPIIRAS Proceedings. 2013. Vol. 13. P. 255-276.

[2] Makeev V.M., Klokov K.B., Kolpaschikov L.A., Mikhailov V.V. Reindeer in a changing climate. SPb.: Lemma, 2014.

[3] Kolpaschikov L.A., Mikhailov V.V., Mukhachev A.D. Ecosystem "reindeer - pastures people". SPb.: Polytechnic, 2011.

[4] Mikhailov V., Kolpaschikov L. Population dynamics of the Taimyr wild reindeer herd // International Journal of Environmental Studies. 2017. Vol. 74. Is. 5. P. 862-883

[5] Kolpaschikov L.A., Mikhailov V.V., Russell D.E. The role of harvest, predators, and sociopolitical environment in the dynamics of the Taimyr wild reindeer herd with some lessons for North America // Ecology and Society. 2015. Vol. 20. Is. 1. DOI:10.5751/ES-07129-200109.

[6] Ivanov K.P. The basics of body energy. Vol. 1. General energy, heat exchange and heat regulation. Leningrad: Science, 1990.

[7] Ivanov K.P. Modern theoretical and practical problems of homoeothermic and thermoregulation // Russian Physiological Journal. 2006. Vol. 92. Is. 5. P. 578-592.

[8] Shmidt-Nielsen K. Animal physiology. Vol. 1. Moscow: Mir, 1982.

[9] Schmidt R.F., Thews G. Human physiology. Switzerland: Springer-Verlag, 1989.

[10] Sokolov A.Ya., Kushnir F.I. Reindeer thermoregulation and bioenergy. Novosibirsk: Izd. SO RAN, 1987.

[11] Cuyler C. Temperature regulation and survival in svalbard reindeer (Rangifer tarandus platyrhynchus). PHd Dissert. Scientiarum. Oslo, 1992.

[12] Ovsov A.S. Thermoregulatory mechanisms of natural adaptations of reindeer. Abstract for PHd Dissert. Leningrad, 1991.

[13] Klokov K.B., Mikhailov V.V. Identification of areas of climatic optimum for traditional reindeer husbandry of the indigenous population of the Yamal-Nenets Autonomous Okrug // Bulletin of St. Petersburg Agrarian University. 2015. Is. 40. P. 105-108.

[14] Klokov K.B., Mikhailov V.V. Assessment of climatic conditions for siberian reindeer herding on the basis of heat balance modelling // ARCTIC. 2019. Vol. 72. Is. 1. P. 28-42. DOI:10.14430/arctic67916. 